\title{
Occurrence and polymorphism of bombesin-like peptides in the gastrointestinal tract of birds and mammals ${ }^{1}$
}

\author{
V. ERSPAMER ${ }^{2}$, G. FALCONIERI ERSPAMER, P. MELCHIORRI, AND \\ L. NEGR I
}

From the Institutes of Medical Pharmacology I and III, University of Rome, Rome, Italy

SUMMARY The gastrointestinal tract of mammals and birds, especially stomach and upper small intestine, contains bombesin-like peptides. This has been unequivocally demonstrated by radioimmunoassay and bioassay. Concentrations of bombesin-like activity may range from a few ng to 500-600 ng per $g$ fresh tissue. Last values refer to the chicken proventriculus, which has been the object of a more thorough investigation. The bombesin-like peptide of the chicken proventriculus showed a marked heterogeneity. All forms probably stem from a pro-bombesin, a large precursor molecule which is insoluble in methanol, acetone, and even boiling water, but may be cleaved by acid hydrolysis. Methanol extracts contain at least two forms of the bombesin-like peptide; $\mathrm{HCl}$ extracts at least three forms; $\mathrm{HCl}$ extracts of the residue of methanol extraction at least four forms. Whereas some forms-for example, the methanol extractable forms-probably pre-exist in the tissue, other forms may be artefacts arising from acid treatment. The various forms may be distinguished from each other not only by their elution profile, but also by bioassay. In fact, though all forms show the activity spectrum characteristic for the amphibian bombesin-like peptides, they present considerable quantitative differences in activity. Pro-bombesin(s) probably occur also in the rat and guinea-pig stomach; similarly, a clear-cut heterogeneity is appreciable for the bombesin-like peptide of the human gastric mucosa.

Amphibian skin may be considered, as repeatedly stated, a store-house of biogenic amines and active peptides.

As a result of studies carried out by our group during the past 15 years on more than 500 amphibian species collected throughout the world, as many as 19 new polypeptides, belonging to six different families, have been isolated in a pure form and, after elucidation of their structure, most of them have been reproduced by synthesis.

All or nearly all amines and peptides found in amphibian skin were shown to have their counterpart in mammalian tissues.

An apparent exception to this situation was represented by the bombesin-like peptides, which com-

\footnotetext{
${ }^{1}$ This study was supported by grants from the Consiglio Nazionale delle Ricerche, Roma, Italy.

${ }^{2}$ Address for correspondence: Professor V. Erspamer, Institute of Medical Pharmacology I, University of Rome, Città Universitaria, I-00185 Rome.

Received for publication 29 June 1979.
}

pletely lacked, when first described, their counterpart in the mammalian organism.

We have since succeeded in demonstrating that the mucosa of the mammalian and avian gut contains one or more peptides with radioimmunological and biological characteristics very similar to those possessed by bombesin and litorin (Erspamer and Melchiorri, 1975, 1976; Erspamer et al., 1978).

\section{Methods}

EXTRACTION PROCEDURES

Materials were removed as soon as the animals were killed or collected during surgery. Stomachs and intestines were opened, washed under running water, wiped with a cloth or filtre paper, then minced with scissors or passed through a flesh grinder. In some cases the mucosa was treated separately from the muscular layer. All other organs were minced with scissors. The following extraction solvents and procedures were used: 
Methanol Tissues were extracted with 4 parts (w/v) methanol and, after standing for 24 hours, were reextracted with another 4 parts $80 \%$ methanol. Tissue fragments were then transferred to a glass filtre and thoroughly washed with $80 \%$ methanol. Final methanol was removed by suction, and filtrates were mixed.

Acetone 1:4 The procedure was the same as that used for methanol.

$\mathrm{HCl} 0.15 \mathrm{~N}$ Tissues were treated in a boiling water bath, for one hour, with 4 parts $0.15 \mathrm{~N} \mathrm{HCl}$. After cooling, the extract was brought to $\mathrm{pH} 6$ with $\mathrm{N}$ $\mathrm{NaOH}$ and then ethanol was added to a final volume of $10 \mathrm{ml}$ per $\mathrm{g}$ tissue. Filtration or centrifugation of the extract was carried out after 24 hours.

Distilled water Tissues were treated in a boiling water bath with 4 vol distilled water. After cooling, the material was centrifuged and an equal volume of ethanol was added to the supernatant.

\section{Bioassay}

The rat uterus preparation, pretreated with atropine $(0.5-1 \mu \mathrm{g} / \mathrm{ml})$, cimetidine $(0.5-1 \mu \mathrm{g} / \mathrm{ml})$, and methysergide $(0 \cdot 2 \mu \mathrm{g} / \mathrm{ml})$, was routinely used in the bioassay of crude extracts and in the follow-up of all extraction, purification, and manipulation procedures. Crude extracts with sufficiently high bombesin-like activity and particularly semi-purified extracts were tested on several other in vitro and in vivo smooth muscle preparations: rat urinary bladder in vitro and in vivo, rat colon, guinea-pig large intestine and urinary bladder, kitten small intestine, guinea-pig gall bladder in situ (Erspamer et al., 1972).

Bombesin-like activity was always expressed in terms of litorin, as the response produced by the gastrointestinal bombesin-like peptide was more similar, in onset, duration, and shape, to that produced by litorin than to that evoked by bombesin.

\section{Radioimmunoassay}

The synthetic C-terminal nonapeptide of bombesin (BN) was coupled to bovine albumin using carbodiimide. The conjugated peptide was separated from the unconjugated compound and from carbodiimide by dialysis. The solution containing coupled $\mathrm{BN}$ was then homogenised with an equal volume of Freund's complete adjuvant. The mixture was injected subcutaneously into 30 rabbits, each animal receiving approximately $200 \mu \mathrm{g} \mathrm{BN}$ at each injection. After six immunisations at three week intervals three out of 30 animals had developed antibodies which at antiserum dilutions of $1: 500,1: 3000$, and 1:50,000 bound $30-50 \%$ of $100 \mathrm{cpm}$ of synthetic C-terminal $\mathrm{Tyr}^{1}$-decapeptide of bombesin $\left(\mathrm{Tyr}^{1}-\mathrm{BD}\right)$ labelled with $\mathrm{I}^{125}$. Tyr ${ }^{1}-\mathrm{BD}$ was labelled to a specific activity of $75-150 \mu \mathrm{Ci} / \mu \mathrm{g}$ with $\mathrm{I}^{125}$ by chloramine $\mathrm{T}$ technique (Greenwood et al., 1963). One millilitre of human plasma was added to the final reaction volume.

Labelled monoiodo $\mathrm{Tyr}^{1}$-BD was then separated from damaged components and unreacted iodine on Sephadex G-25 eluted with 0.1 M ammonium acetate, $\mathrm{pH} 5$.

Two millilitres of a $0.02 \mathrm{M}$ solution of barbital buffer containing $2 \%$ direct rabbit plasma and $2 \%$ human serum albumin, various dilutions of antiserum, and 1000-2000 cpm of labelled $\mathrm{Tyr}^{1}-\mathrm{BD}$ were added to $0.25 \mathrm{ml}$ of undiluted plasma or to different dilutions of tissue extracts. Controls containing no antiserum were run for all tested samples of plasma and tissue extracts to permit correction for incubation damage. The mixtures were incubated for 48 hours at $4^{\circ} \mathrm{C}$ before separating the free $\mathrm{Tyr}^{1}$-BD from the antibody-bound peptide. Separation was carried out with charcoal in ice-water. $0.15 \mathrm{ml}$ of a charcoal suspension $(25 \mathrm{mg} / \mathrm{ml})$ in $0.02 \mathrm{M}$ barbital buffer, $\mathrm{pH} 8.6$, was added to each tube containing plasma. $0.25 \mathrm{ml}$ of human plasma was added to tubes devoid of plasma, before the addition of charcoal. After mixing, the tubes were centrifuged in a refrigerated centrifuge $(2000 \mathrm{rpm}$ per $10 \mathrm{~min}$ ).

The supernatant was decanted and the tubes containing both charcoal and supernatant were counted in an automatic scintillation well counter. In routine assays, the addition of $10 \mathrm{pg}$ of $\mathrm{BN}$ to incubation mixture reduced the $\mathrm{B} / \mathrm{F}$ ratio to below $80 \%$ of the corresponding $\mathrm{B} / \mathrm{F}$ ratio in a solution containing no BN. Detection limit of the assay for BN was of the order of 3-4 pg/ml. When tissue extracts from animals and man were diluted and tested over an eight-fold and five-fold concentration range, respectively, dilution curves could not be distinguished from the standard curves prepared in buffer.

On the contrary, human and dog plasma diluted and tested on a five-fold concentration range gave dilution curves statistically different from the standard curves. This fact may indicate that the bombesin-like immunoreactivity demonstrated in man and dog plasma is not necessarily due to the presence of the same bombesin-like peptide occurring in tissues.

No cross-reactions were found between the antibody and human gastrin I, cholecystokinin, caerulein, secretin, glucagon, VIP, GIP, somatostatin, substance $\mathbf{P}$, and eledoisin. However, on a molar basis, the ratio between the dose producing $50 \%$ inhibition $\left(\mathrm{ID}_{50}\right)$ for $\mathrm{BN}$ and similar peptides was as follows: bombesin $1 \cdot 0$, litorin 0.38 , C-terminal tripeptide of bombesin 0.01, BOC-Gln-Trp-Ala-Val-Gly 0.65. 


\section{Chemicals}

Bombesin, litorin, C-terminal nonapeptide of bombesin (BN), C-terminal Tyr ${ }^{1}$-decapeptide of bombesin (Tyr $\left.{ }^{1}-\mathrm{BD}\right)$ were synthesised at the Farmitalia S.p.A. Research Laboratories, Milan. $\mathrm{Nal}^{125}$ and charcoal were obtained from Sorin, Saluggia, Italy.

Other substances used were as follows: carbodiimide and alkaline alumina, activity grade I (Merck, Darmstadt), Sephadex G-10 and G-25 superfine (Pharmacia, Uppsala), bovine albumin (Calbiochem, Los Angeles), human serum albumin (Sclavo, Siena), Elgalite resin (Elga Prod., Lane End, Bucks), Freund's adjuvant (Grand Island Biol. Co., Berkeley, California), methysergide, cimetidine, and mepyramine maleate.

\section{Results}

EXTRACTION OF BOMBESIN-LIKE POLYPEPTIDE Most experiments were carried out on the chicken proventriculus. It soon appeared evident that the extraction procedure invariably giving the greatest yields of bombesin-like activity was boiling with $0.15 \mathrm{~N} \mathrm{HCl}$, while the poorest results were obtained with acetone extraction. Considering the yield obtained with methanol to be equal to 100 , yields obtained with the other solvents were as follows: acetone $60-80$, boiling distilled water 100-140, boiling $0 \cdot 15 \mathrm{~N} \mathrm{HCl} 200-400$.

Table 1 shows results obtained on methanol and acid extracts of several batches of chicken proventriculus and three batches of gizzard mucosa, by bioassay (BIOA), using the rat uterus preparation (ng litorin/g fresh tissue), and radioimmunoassay (RIA, ng bombesin/g fresh tissue).

Acid treatment at $38^{\circ} \mathrm{C}$ for one to three hours gave very low contents of bombesin-like activity, corresponding to approximately $10 \%$ of those obtained at $100^{\circ} \mathrm{C}$.

The reason for the particular effectiveness of acid extraction at $100^{\circ} \mathrm{C}$ was investigated as follows.

Fifty chicken proventriculi, weighing $390 \mathrm{~g}$, were passed through a flesh grinder and the material was thoroughly mixed.

1. Sixty grams were extracted twice with 4 vol. methanol and the tissue fragments were washed with $80 \%$ methanol (methanol extract). Thereafter the material was boiled with $0.15 \mathrm{~N} \mathrm{HCl}$ (methanol $\mathrm{HCl}$ extract).

2. Sixty grams were extracted as above with methanol (methanol extract) and the residue was boiled with distilled water (methanol water extract).

3. Sixty grams were extracted with 4 vol. acetone and treated as in method 1 (acetone extract and acetone $\mathrm{HCl}$ extract).

4. Sixty grams were first extracted with boiling distilled water (water extract) and then re-extracted with boiling $\mathrm{HCl}$ (water $\mathrm{HCl}$ extract).

5. Sixty grams were boiled for 60 minutes with $0.15 \mathrm{~N} \mathrm{HCl}$ ( $\mathrm{HCl}$ extract).

Fig. 1 shows that acid treatment of proventricular tissue first exhausted with methanol or distilled water caused release of additional large amounts of bombesin-like activity, exceeding those obtained in the first extraction.

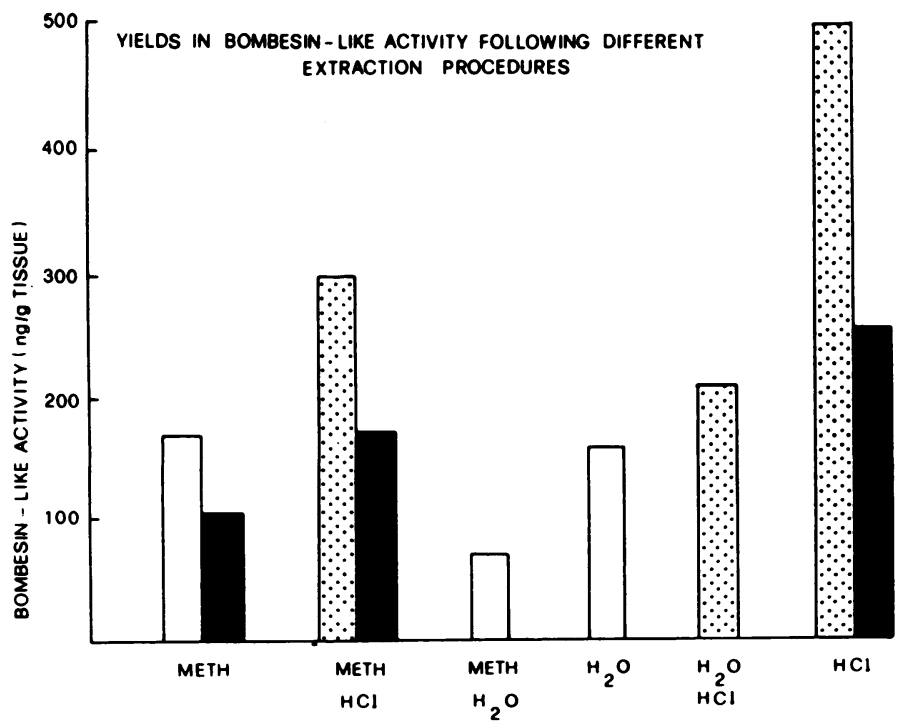

Fig. 1 Yields of bombesin-like activity after extraction of chicken proventriculus with various solvents. $M E T$, methanol extraction; $\mathrm{MET} \mathrm{HCl}$, boiling $0.15 \mathrm{~N} \mathrm{HCl}$ extraction of tissue exhausted with methanol; $\mathrm{H}_{2} \mathrm{O}$, boiling distilled water extraction; $\mathrm{MET} \mathrm{H}_{2} \mathrm{O}$, boiling distilled water extraction of tissue exhausted with methanol; $\mathrm{HCl}$, boiling 0.15 $\mathrm{N} \mathrm{HCl}$ extraction. Open columns, bioactivity of methanol and water extracts expressed as ng litorin per $\mathrm{g}$ fresh tissue (rat uterus preparation); stippled columns, bioactivity of $\mathrm{HCl}$ extracts, expressed as above; solid columns, immunoreactivity, expressed as ng bombesin/g tissue. 
Table 1 Chicken proventriculus and gizzard: comparative yields in bombesin-like activity after methanol and $\mathrm{HCl}$ extraction

\begin{tabular}{|c|c|c|c|c|c|}
\hline \multirow[t]{2}{*}{ Batch } & \multirow[t]{2}{*}{ Tissue } & \multicolumn{2}{|c|}{$\begin{array}{l}\text { Methanol } \\
\text { extract }\end{array}$} & \multicolumn{2}{|c|}{$\mathrm{HCl}$ extract } \\
\hline & & $B I O A$ & $R I A$ & $B I O A$ & $R I A$ \\
\hline 1975/D (28) & $\begin{array}{l}\text { Pr } \\
\text { Giz }\end{array}$ & $\begin{array}{l}60-80 \\
35-50\end{array}$ & $\begin{array}{l}50 \\
35\end{array}$ & $\begin{array}{l}= \\
=\end{array}$ & $\begin{array}{l}= \\
=\end{array}$ \\
\hline $1975 / F \quad(40)$ & $\begin{array}{l}\text { Pr } \\
\text { Giz }\end{array}$ & $\begin{array}{c}100-150 \\
70-90\end{array}$ & $\begin{array}{r}120 \\
=\end{array}$ & $\begin{array}{c}500-600 \\
120\end{array}$ & $\begin{array}{r}210 \\
90\end{array}$ \\
\hline 1975/G (136) & $\begin{array}{l}\text { Pr } \\
\text { Giz }\end{array}$ & $\begin{array}{l}70-120 \\
40-70\end{array}$ & $\begin{array}{r}80 \\
130\end{array}$ & $\begin{array}{r}240-300 \\
50-100\end{array}$ & $\begin{array}{r}180 \\
80\end{array}$ \\
\hline 1975/H (48) & Pr & $150-170$ & $=$ & $600-700$ & $=$ \\
\hline $1975 / I \quad(124)$ & Pr & $80-100$ & $=$ & $300-350$ & $=$ \\
\hline $1975 / \mathrm{L}(70)$ & Pr & $110-130$ & $=$ & $350-400$ & $=$ \\
\hline 1975/M (60) & Pr & $110-120$ & $=$ & $300-350$ & $=$ \\
\hline $1975 / N(47)$ & Pr & $80-100$ & $=$ & $250-300$ & $=$ \\
\hline $1975 / O$ & Pr & $60-80$ & $=$ & $200-250$ & $=$ \\
\hline Pool 1976 (1237) & Pr & $=$ & $=$ & $400-500$ & $=$ \\
\hline Pool 1977 (1970) & Pr & $=$ & $=$ & $150-200$ & $=$ \\
\hline $1977 / X(40)$ & Pr & 170 & 120 & 500 & 170 \\
\hline 1978/A (36) & Pr & 50 & 41 & 100 & 65 \\
\hline
\end{tabular}

Number of chickens in parentheses. BIOA, bioassay (ng litorin/g tissue); RIA, radioimmunoassay (ng bombesin/g tissue); $\mathrm{Pr}$, whole proventriculus; giz, gizzard mucosa; =, not investigated.

Boiling the residues of methanol extraction with distilled water was approximately four times less effective than acid treatment.

The above experiments, repeated three times, gave results comparable with those shown in Fig. 1. Similarly, large amounts of bombesin-like activity were released by acid post-treatment of tissue fragments first exhausted with 80 or $90 \%$ acetone.

Although confirming the results of bioassay, radioimmunoassay gave consistently smaller values of bombesin-like activity. This was particularly evident in the case of direct acid extraction.

On the basis of the above results, at first extraction with boiling $0 \cdot 15 \mathrm{~N} \mathrm{HCl}$ was most frequently used in our first large scale preparations of crude proventricular extracts. It later appeared, however, from gel filtration experiments on Sephadex G-25 that the proventricular bombesin-like peptide presented a considerable heterogeneity and that the forms occurring in acid extracts were not necessarily the same as those occurring in methanol extracts.

As a consequence three types of extracts were submitted to a separate study: methanol extracts, acid extracts, and acid extracts subsequent to methanol extraction.

Results obtained in the chicken proventriculus cannot be generalised and extended to other avian or mammalian tissues, not even to the mucosa of the chicken gizzard.

In fact, acid extraction of this tissue yielded amounts of biological activity only $35-45 \%$ greater than those obtained by methanol, and acid post- treatment of gizzard mucosa first exhausted with methanol released poor additional amounts of bioactivity and immunoreactivity: 20 and $40 \%$, respectively, of amounts occurring in methanol extracts.

As far as the mammalian gastrointestinal tract is concerned, only a few preliminary data can be presented, essentially confirming results obtained in the chicken proventriculus.

Rat stomach (pool from 83 animals): methanol extract, 30-60 ng/g litorin; methanol $\mathrm{HCl}$ extract, $20-40 \mathrm{ng} / \mathrm{g}$. Guinea-pig stomach (pool from 28 animals): methanol extract $10-20 \mathrm{ng} / \mathrm{g}$ litorin: methanol $\mathrm{HCl}$ extract $30-70 \mathrm{ng} / \mathrm{g}$.

\section{Occurrence of bombesin-like activity in mammalian and avian tissues}

Bombesin-like activity in methanol and acid tissue extracts was determined by bioassay and radioimmunoassay. For bioassay the uterus preparation was used, and bombesin-like activity was expressed in terms of litorin.

The sensitivity of the rat uterus to litorin varied between 0.1 and $0.5 \mathrm{ng}$ per $\mathrm{ml}$ bath solution. Tachyphylaxis occurred irregularly. In the case of crude extracts with low concentrations of bombesinlike activity, contaminants considerably interfered with bioassay, making values of bombesin-like activity below 5-10 $\mathrm{ng} / \mathrm{g}$ unreliable.

As already stated, radioimmunoactivity of the extracts was expressed in terms of bombesin.

Results are shown below. Values not in parentheses were obtained by bioassay (ng litorin/g fresh tissue), values in parentheses by radioimmunoassay (ng bombesin/g fresh tissue).

Rabbit Methanol extracts (pool from five animals): gastric antrum 50-80 (105), gastric fundus 20-30 (42); small intestine, proximal quarter 6-7 (2-4), second quarter 6-7 $(<1)$, third quarter 8-10 $(<1)$ distal quarter $10(<1)$, caecum 8-9 $(<1)$, large intestine 6-7 $(<1)$, liver, lung, kidney, heart, spleen, and urinary bladder $<5(<1)$.

Acid extracts (pool from four animals): gastric fundus 30-90; antrum 15-30; small intestine, proximal third 10-20.

Cat Methanol extracts (pool from two animals): antral mucosa 8-10 (3-4), fundic mucosa 10-15; small and large intestine $<5(<1)$; gall bladder, pancreas, liver, kidney, heart, lung, spleen, urinary bladder, uterus, ovary, testicles $<5(<1)$.

Acid extracts (pool from two animals): whole stomach 15-20; small intestine, proximal third 10-20.

Dog Methanol extracts (pool from three animals): fundic mucosa 15-20 (8), antral mucosa 10-15 (10-12), duodenal, jejunal, and ileal mucosa 5 
$(<1)$, caecal+large bowel mucosa 5-15 $(<1)$, pancreas 5-10 (10-15).

Acid extracts (pool from three animals): antral mucosa 30 , fundic mucosa 40 , whole duodenum 60-70.

Rat Methanol extracts (pools from 10, 16, and 27 animals): stomach $30-50,25-40,70$; small intestine, proximal half $30-40,60$. Acid extracts (pool from 12 animals): antrum 50-60, fundus $20-30$, small intestine, proximal half $30-40$.

Pig (Mini-pig, pool from three animals). Methanol extracts: gastric mucosa 40-70. Acid extracts: antral mucosa 35 (35-40), fundic mucosa 40-50 (55-60), whole duodenum 40-50 (60-70), whole ileum 20-30 (15-30).

Guinea-pig Methanol extracts (pools from five, 20, and 28 animals): whole stomach 20-40, 25-50, 10-20; small intestine proximal half 30-40. Acid extracts (pool from five animals): whole stomach 50-80, small intestine proximal half 50-60.

Man Methanol extracts (pool of 15 stomachs): antral plus adjacent fundic mucosa 30-70. Acid extracts (pool of 20 stomachs): antral plus adjacent fundic mucosa 20-60. Boiling water extract (pool from three patients): fundic (20-25), antral (35-50), duodenal (70-105), ileal (28-30), and colonic (17-25) mucosa.

Turkey Acid extracts (pool from five animals): proventriculus $250-400$.

Pigeon Acid extracts (pool from five animals): proventriculus 500-700.

Chicken Methanol and acid extracts: proventriculus and gizzard (Table 1). Methanol extracts: proximal, middle, and distal small intestine $<5$ $(<1)$, caecum, cloaca, liver, pancreas, gall bladder, lung, kidney, heart, testes, and spleen $<5(<1)$.

\section{PURIFICATION OF PROVENTRICULUS \\ EXTRACTS \\ Elgalite resin}

Only acid extracts were treated with Elgalite resin in order to remove salts and biogenic amines. In a typical experiment 201 of the neutralised acid extract + ethanol, corresponding to $2 \mathrm{~kg}$ chicken proventriculi, were passed through three columns, each containing $1 \mathrm{~kg}$ Elgalite resin. Columns were then washed each with $1150 \%$ ethanol, which was added to the preceding effluents. The original extract contained, per $\mathrm{g}$ fresh tissue, $38.8 \mathrm{mg} \mathrm{NaCl}, 22 \mu \mathrm{g}$ histamine base, and $<0.5 \mu \mathrm{g} 5$-HT base; the effluent $0.08 \mathrm{mg} \mathrm{NaCl}$, and $<0.05 \mu \mathrm{g}$ histamine and 5-HT.

\section{Alcohol precipitation}

The combined effluents from the Elgalite columns were evaporated to dryness under reduced pressure at $50-60^{\circ} \mathrm{C}$ and the residue was taken up, with stirring, with $20 \mathrm{ml}$ water plus $180 \mathrm{ml}$ ethanol for each aliquot of $100 \mathrm{~g}$ fresh tissue. After standing overnight at $3-4^{\circ} \mathrm{C}$, the clear supernatant was decanted and the precipitate redissolved, as above, in water plus ethanol. The supernatant was again decanted after 24 hours and the precipitate redissolved for a third time in water plus ethanol. The combined supernatants contained approximately $85 \%$ of the activity present in the effluents from Elgalite columns.

\section{Chromatography on alumina columns}

Both the above supernatant and genuine methanol extracts (methanol was evaporated and the residue taken up with $90 \%$ ethanol) were loaded on columns of different size containing $100 \mathrm{~g}$ alkaline alumina per $70-100 \mathrm{~g}$ tissue. Elution was carried out with descending concentrations of ethanol, starting with $90 \%$ ethanol, and terminating with water. Volumes of the eluates were $100 \mathrm{ml}$ per $100 \mathrm{~g}$ alumina.

Results obtained in three typical experiments carried out with an $\mathrm{HCl}$ extract (2000 g tissue), a methanol extract (470 $\mathrm{g}$ tissue), and a methanol $\mathrm{HCl}$ extract ( $700 \mathrm{~g}$ tissue) are presented in Table 2.

Table 2 Bombesin-like activity (ng litorin/g) of ethanol eluates from alumina columns loaded with three different proventricular extracts

\begin{tabular}{|c|c|c|c|}
\hline Ethanol eluate & $\mathrm{HCl}$ extract & Methanol extract & $\begin{array}{l}\text { Methanol } \mathrm{HCl} \\
\text { extract }\end{array}$ \\
\hline $\begin{array}{l}90_{1} \\
90_{2} \\
85_{1} \\
85_{2} \\
80_{1} \\
80_{2} \\
70_{1} \\
70_{2} \\
60 \\
50 \\
40 \\
30 \\
\mathrm{H}_{2} \mathrm{O} \\
\text { Material applied } \\
\text { on column }\end{array}$ & 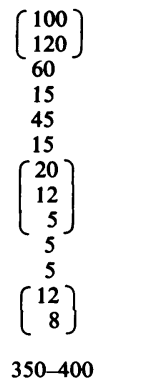 & 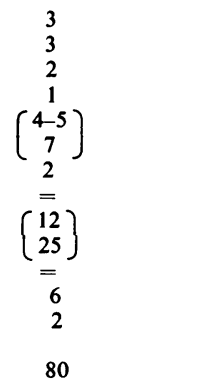 & $\begin{array}{c}{\left[\begin{array}{c}10 \\
5 \\
2\end{array}\right]} \\
= \\
{\left[\begin{array}{c}15 \\
20\end{array}\right]} \\
8 \\
= \\
{[15]} \\
= \\
2 \\
= \\
{[12]} \\
110-120\end{array}$ \\
\hline
\end{tabular}

Single eluates or pools of eluates submitted to gel filtration on Sephadex G-25 are in brackets.

The elution profile, from an alumina column, of the bombesin-like activity present in the acid extract of the chicken proventriculus is shown in Fig. 2. Bombesin-like activity, which was particularly high in this experiment, was estimated both by bioassay and radioimmunoassay.

Whereas both methods concordantly showed a major peak of activity in eluates $90_{1}+90_{2}+85_{1}$, and minor peaks in eluates 70 and $30+\mathrm{H}_{2} \mathrm{O}$, the con- 


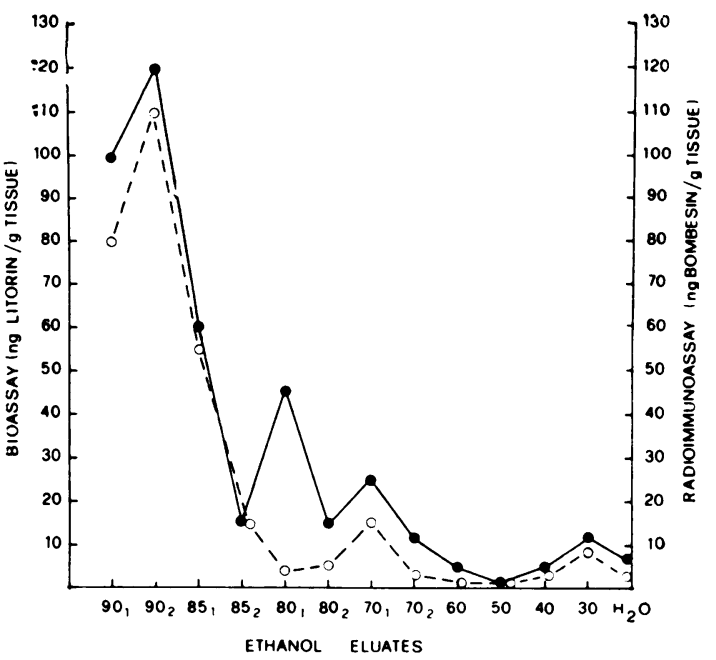

Fig. $2 \mathrm{HCl}$ extract of chicken proventriculus. Elution of bombesin-like activity from alkaline alumina column by means of descending concentrations of ethanol and water. BIOA: - bioactivity, determined on the rat uterus preparation and expressed as ng litorin/g tissue; RIA: o- - - - o immunoreactivity, expressed as ng bombesin/g tissue.

sistent peak found by bioassay in eluate $80_{1}$ was not appreciable, for unknown reasons, by radioimmunoassay.

When tested on the guinea-pig ileum, eluates $90_{1}$, $90_{2}$, and $85_{1}$ contained less than $30 \mathrm{ng} / \mathrm{g}$ histamine, all other eluates less than $60 \mathrm{ng} / \mathrm{g}$ and the small stimulant effect elicited by these eluates was qualitatively different from that provoked by histamine and was resistant to mepyramine. 5-HT was not present in detectable amounts in any of the eluate $(<50 \mathrm{ng} / \mathrm{g})$. The disturbing interference of amine contaminants was thus completely eliminated.

It should be stressed that, in other experiments, using the same type of extract, the elution profile, although similar, differed in the reciprocal magnitude of the various peaks of activity.

\section{GEL FILTRATION}

While both Sephadex G-15 and G-25 superfine were used, the majority of experiments were carried out with G-25 $(1.6 \times 100 \mathrm{~cm}$ column). In each case the equivalent of 50 to $100 \mathrm{~g}$ of fresh proventricular tissue ( $=30-200 \mathrm{mg}$ dry residue) was applied to the column. Bovine serum albumin $(10 \mathrm{mg})$ and $\mathrm{NaCl}$ $(0.2 \mathrm{mg})$ were added as markers to all samples. The protein peak was estimated by absorbance at $280 \mathrm{~nm}$, $\mathrm{Na}^{+}$by flame photometry.

Unless otherwise stated, elution was performed with $0.1 \mathrm{M}$ formic acid ( $3 \mathrm{ml} / 18 \mathrm{~min}$ ).
The various eluates were submitted to bioassay and, in some cases, also to radioimmunoassay. Bioassay was carried out, after neutralisation with $\mathrm{N} \mathrm{NaOH}$, on the rat uterus preparation using litorin as a standard. As the activity ratio between litorin and the unknown bombesin-like constituents occurring in the eluates may vary considerably in different experiments, the values obtained in bioassay are only indicative of eluate volumes and peaks of activity. Radioimmunoassay, carried out with the antiserum available, has the same limitations, considering the different affinity to the bombesin antibody of the different bombesin-like peptides.

In separate runs the Sephadex columns were calibrated with synthetic litorin and bombesin.

\section{Alumina eluates of the methanol extract}

Ethanol eluates $80_{1}+80_{2}$ and $50+60$ were applied separately on Sephadex columns. Elution profiles are shown in Fig. 3.

It may be seen that both eluates $80_{1}+80_{2}$ and $50+60$ produced two peaks of litorin-like activity, with elution volumes (expressed as \% from protein peak, $\%$, to $\mathrm{NaCl}, 100 \%$ ) of $3 \%$ and $63 \%$ (litorin equivalents 1.7 and $8.7 \mathrm{ng} / \mathrm{g}$ wet tissue), and $6 \%$ and $69 \%$, respectively ( 5 and $82 \mathrm{ng} / \mathrm{g}$ ). In each run the minor peak emerged soon after protein, the major ust before bombesin. The minor peaks produced a uterine response characterised by slow relaxation, upon washing, interrupted by contraction waves; the major peaks by prompt and complete relaxation.

\section{Alumina eluates of the $\mathrm{HCl}$ extract}

The three groups of eluates $90_{1}+90_{2}, 70_{1}+70_{2}+60$, and $30+\mathrm{H}_{2} \mathrm{O}$ were applied separately on Sephadex columns. Elution profiles are shown in Fig. 4.

Peaks of litorin-like activity appeared with elution volumes of $10 \%(4 \mathrm{ng} / \mathrm{g})$ and $127 \%(140 \mathrm{ng} / \mathrm{g})$ for ethanol eluates $901+90$, volumes of $10 \%(4 \mathrm{ng} / \mathrm{g})$ and $78 \%(17 \mathrm{ng} / \mathrm{g})$ for ethanol eluates $70_{1}+70_{2}+60$, and finally volumes of $25 \%(<1 \mathrm{ng} / \mathrm{g})$ and $79 \%$ $(14.5 \mathrm{ng} / \mathrm{g})$ with ethanol eluates $30+\mathrm{H}_{2} \mathrm{O}$.

In the $90_{1}+90_{2}$ run the major peak emerged in the same position as litorin and behaved like litorin in the rat uterus preparation, showing a slow relaxation pattern upon washing. This component is probably that most closely resembling litorin. The two major peaks appearing in the $70_{1}+70_{2}+60$ and in the $30+\mathrm{H}_{2} \mathrm{O}$ runs had the same elution volumes of $78-79 \%$, and emerged between calibration standards of bombesin and litorin. The uterine response was characterised by prompt relaxation upon washing. The minor peaks, on the contrary, all presented slow relaxation.

Alumina eluate $80_{1}$, showing a large amount of litorin-like activity (cf. Table 2 ), gave unexpectedly 


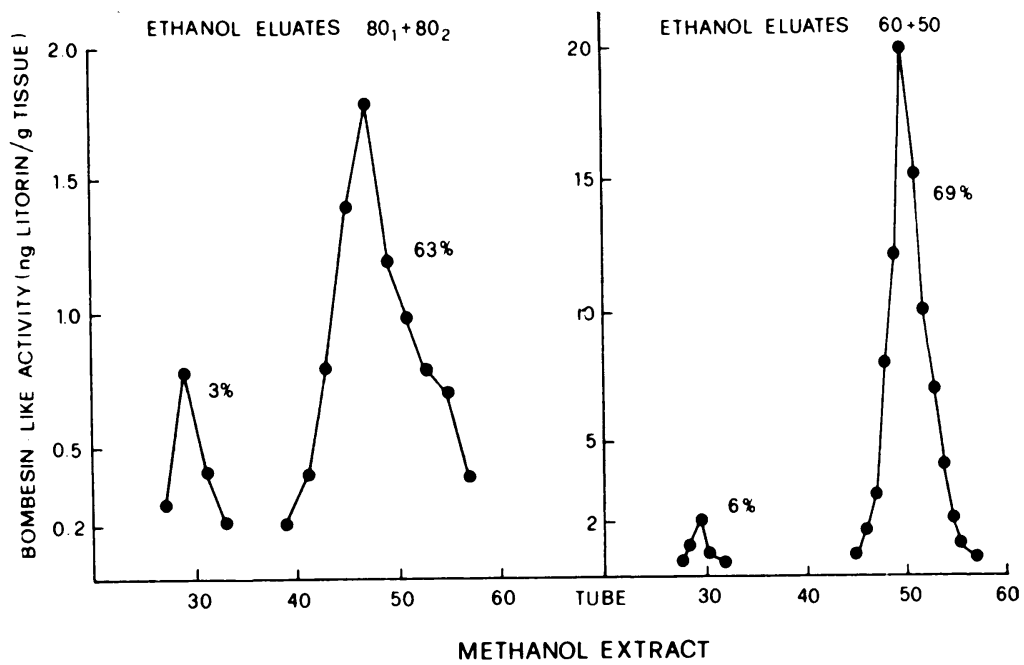

Fig. 3 Heterogeneity of the bombesin-like peptide occurring in methanol extracts of chicken proventriculus. Ethanol eluates $8 \mathrm{O}_{1}+8 \mathrm{O}_{2}$ and $50+60$ obtained from an alkaline alumina column loaded with the crude methanol extract were applied to Sephadex G-25 columns $(1.6 \times 100 \mathrm{~cm})$ in equivalents corresponding to 50-100 g tissue. Filtration was carried out with $0.1 \mathrm{M}$ formic acid $(3 \mathrm{ml} / 18 \mathrm{~min})$. The figure shows the elution profile of the bombesin-like activity occurring in the two ethanol eluates, as determined on the rat uterus preparation and expressed in $n g$ litorin per $g$ fresh tissue. Elution volumes of the bioactivity peaks are expressed as \% from protein peak $(0 \%)$ to $\mathrm{NaCl}$ peak $(100 \%)$.

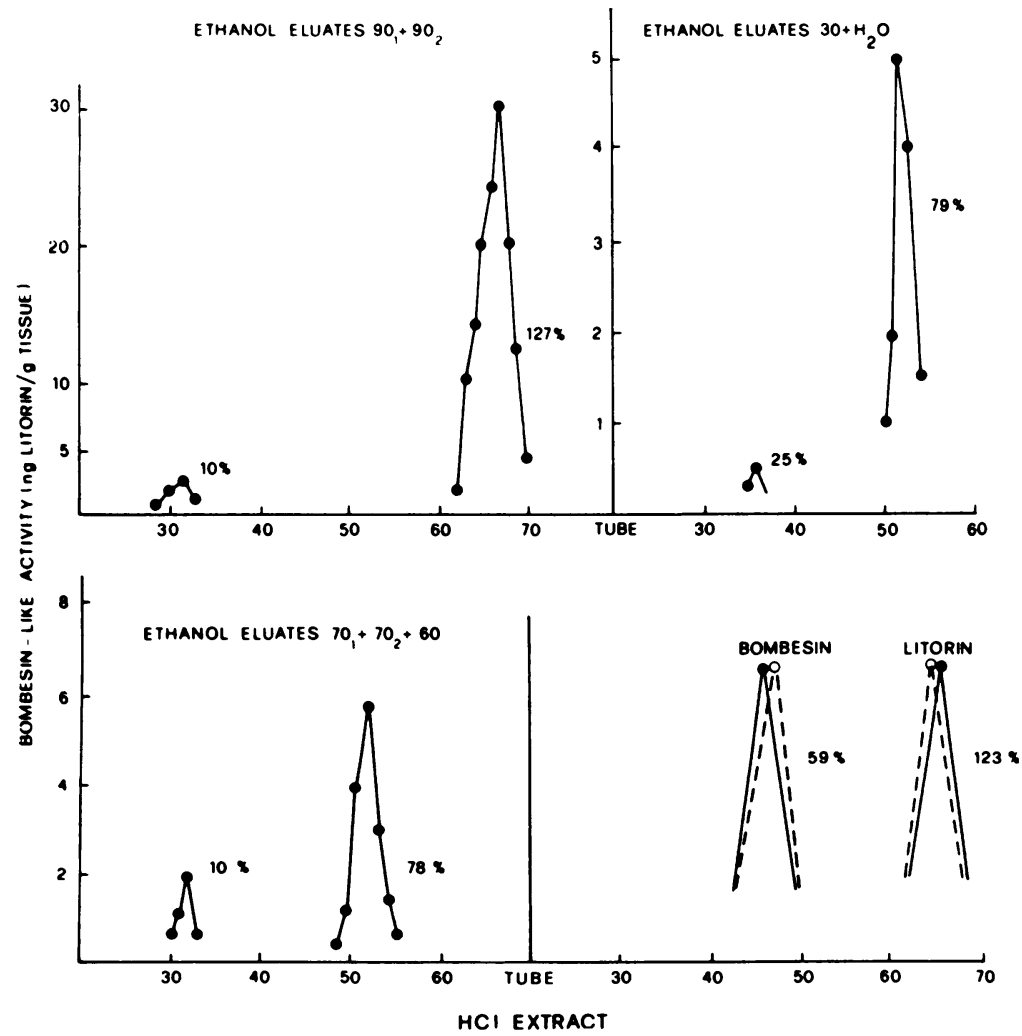

Fig. 4 Heterogeneity of the bombesin-like peptide occurring in $\mathrm{HCl}$ extracts of chicken proventriculus. Ethanol eluates $90_{1}+90_{2}, 70_{1}+70_{2}+60$, and $30+\mathrm{H}_{2} \mathrm{O}$ obtained from an alkaline alumina column loaded with the crude $\mathrm{HCl}$ extract were applied on Sephadex G-25 columns. The figure shows the elution profile of the bombesinlike activity occurring in the three ethanol eluates (rat uterus preparation, $\mathrm{ng} / \mathrm{g}$ litorin).

Elution volumes of the bioactivity peaks are expressed as \% from protein peak $(0 \%)$ to $\mathrm{NaCl}$ peak (100\%). The Sephadex columns were calibrated in two separate runs with synthetic bombesin $(20 \mu g)$ and litorin $(20 \mu g)$. 


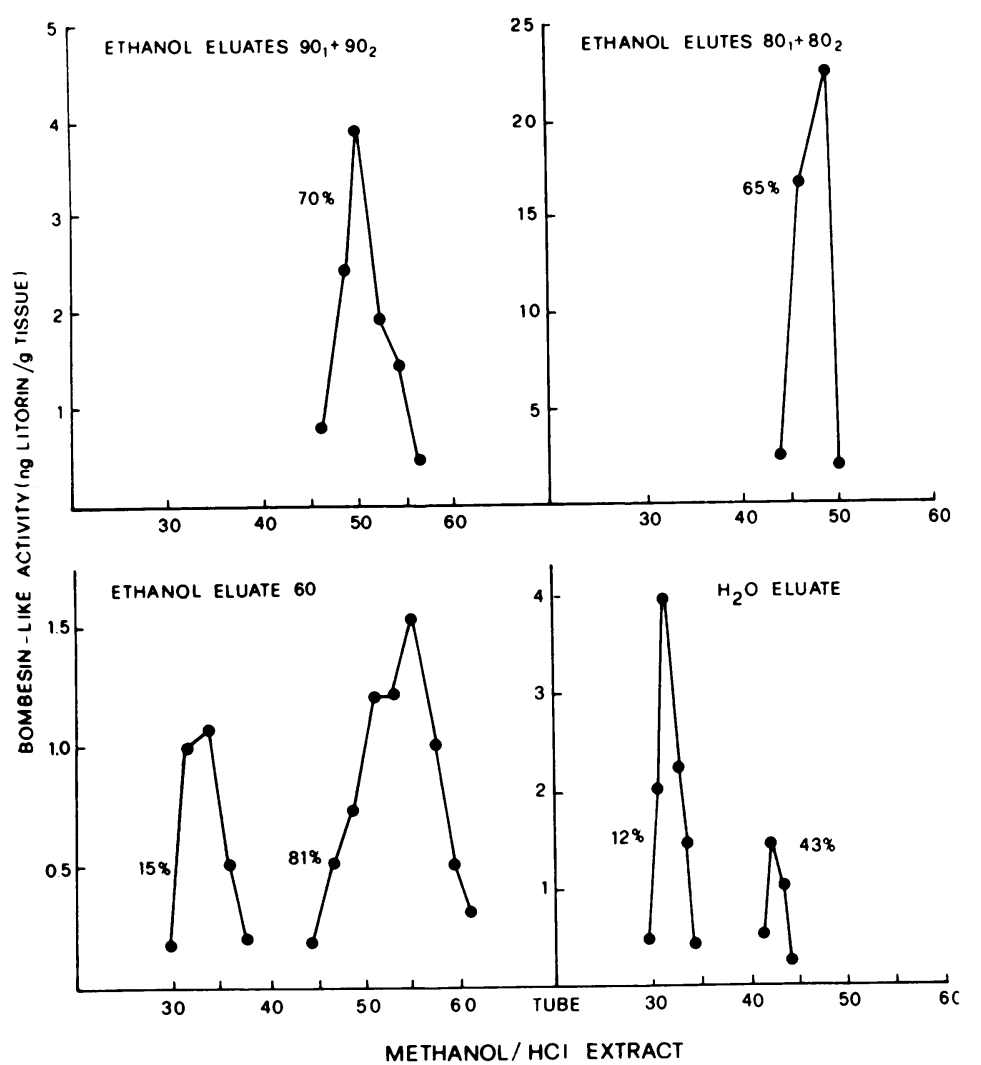

Fig. 5 Heterogeneity of the bombesin-like peptide occurring in $\mathrm{HCl}$ extracts of chicken proventricular tissue previously exhausted with methanol (MET $\mathrm{HCl}$ extract). Ethanol eluates $90_{1}+90_{2}$, $80_{1}+80_{2}, 60$ and water eluate obtained from an alkaline alumina column loaded with the $\mathrm{MET} \mathrm{HCl}$ extract were applied on Sephadex G-25 columns. The figure shows the elution profiles of bombesin-like activity present in the four different alumina eluates (rat uterus preparation, $n g / g$ litorin). Elution volumes of the bioactivity peaks are expressed as \% from protein peak $(0 \%)$ to $\mathrm{NaCl}$ peak $(100 \%)$. low recoveries of this activity $(<10 \%)$ when applied to a Sephadex column. It was not further investigated.

\section{Alumina eluates of the methanol $\mathrm{HCl}$ extract}

Eluates $90_{1}+90_{2}, 80_{1}+80_{2}, 60$ and $\mathrm{H}_{2} \mathrm{O}$ from alumina columns were separately applied on Sephadex columns. Results are shown in Fig. 5.

Peaks of litorin-like activity appeared with elution volumes of $70 \%(11.3 \mathrm{ng} / \mathrm{g})$ for the $90_{1}+90_{2}$ run, $65 \%(42.5 \mathrm{ng} / \mathrm{g})$ for the $80_{1}+80_{2}$ run, $16 \%(3 \mathrm{ng} / \mathrm{g})$ and $81 \%(7 \mathrm{ng} / \mathrm{g})$ for the $60 \mathrm{run}$, and $12 \%(11 \mathrm{ng} / \mathrm{g})$ and $43 \%(3 \cdot 1 \mathrm{ng} / \mathrm{g})$ for the $\mathrm{H}_{2} \mathrm{O}$ run. Peaks in the 90 and 80 runs and the major peak in the 60 run emerged between calibration standards of bombesin and litorin; all other peaks emerged between protein and bombesin. The peak in the 90 run and the major peak in the 60 run produced a uterine response of prompt offset upon washing; all other peaks showed slow relaxation.

\section{Biological activity of proventricular bombesin-like peptide}

The most thoroughly studied form of the proventricular bombesin-like peptide was the main form emerging from the Sephadex columns loaded with alumina eluate $90_{1}+90_{2}$ of the $\mathrm{HCl}$ extract (Fig.4). This form, which presented an elution volume similar to that of litorin, displayed, in vivo and in vitro, all the characteristic effects of bombesin-like peptides: it stimulated isolated preparations of rat uterus, large intestine and urinary bladder, guineapig ileum and urinary bladder, kitten small intestine; it produced a modest litorin-like rise of dog blood pressure, it induced in the dog a gastrin release (from 55 to $235 \mathrm{pg} / \mathrm{ml}$ plasma) with ensuing stimulation of gastric acid secretion; it contracted the in situ gall bladder of the guinea-pig and the dog and elicited a pancreatic secretion rich in amylase in the dog and the rat; finally it provoked changes in the electrical activity of the dog stomach and intestine similar to those evoked by bombesin.

Study of the other forms, shown in Figs. 3-5, is in progress and parallel bioassay will probably contribute to their reciprocal distinction. It has already been demonstrated that their activity spectrum, although similar in each case, presented marked quantitative differences. To remain in the field of smooth muscle preparations it could be seen that 
effects on the rat uterus and urinary bladder, guineapig ileum and gall bladder, and kitten small intestine varied conspicuously in intensity and duration and in shape of the contraction curve. Generally, the forms emerging from the Sephadex columns near protein were characterised by a longer lasting action.

The above mentioned bombesin-like effects of purified proventricular extracts (Erspamer and Melchiorri, 1976, 1977; Erspamer et al., 1978) have been confirmed by McDonald et al. (1978) using a purified extract of porcine upper small intestine.

\section{Discussion}

The present research demonstrates that, like all other peptide families of the amphibian skin, that of the bombesin-like peptides also has its counterpart in the mammalian and avian organism. In fact, the gastrointestinal mucosa of all the species of mammals and birds examined contained one or more peptides which can be ascribed to the group of bombesin-like peptides.

Evidence in support of this statement is as follows. Firstly, crude extracts of stomach and intestine of different animals species as well as semi-purified extracts presented a bombesin-like immunoreactivity using anti-bombesin sera obtained from rabbits. Immunoreactive bombesin showed values ranging between a few ng and 150-200 ng per $\mathrm{g}$ fresh tissue, Secondly, semi-purified and purified extracts of chicken proventriculus displayed in vitro (isolated smooth muscle preparations) and in vivo (in situ smooth muscle preparations, dog blood pressure, gastric and pancreatic secretion, electrical and mechanical activity of the gut) exactly the same effects as amphibian bombesin-like peptides. No other known peptide family possesses the characteristic activity spectrum of bombesin-like peptides.

On the other side, Polak et al. (1976), using the immunofluorescence technique, were able to see in all areas of the human gastrointestinal mucosa investigated cells specifically stained with antibodies to bombesin. In the human gut bombesin-like immunoreactivity occurred also in sparse, varicose nerve fibres (Polak et al., 1978b).

Finally, bombesin-like immunoreactivity could be demonstrated also in blood of human subjects, where it rose after a conventional meat meal from very low fasting levels to levels comparable with those of gastrin (Erspamer and Melchiorri, 1976).

Since the publication of our preliminary communications (Erspamer and Melchiorri, 1975, 1976), the occurrence of bombesin-like immunoreactivity in the gastrointestinal tract has been confirmed by others (Lechago et al., 1978; Polak et al., 1978a, 1978b; Walsh and Dockray, 1978). Similarly, the immuno- cytochemical studies of Polak et al. (1976) were extended and confirmed (Lechago et al., 1978; Polak et al., 1978b).

The second important finding emerging from the present research was that the bombesin-like peptide occurring in the chicken proventriculus showed a marked heterogeneity, recalling that described by Rehfeld (1978) for CCK.

First of all, the proventriculus contained a bombesin form which, in analogy with the nomenclature used for other peptides (insulin, endorphins, $\mathrm{ACTH}$, etc.) may be called pro-bombesin.

Pro-bombesin is a large, biologically inactive precursor molecule, insoluble in methanol, acetone, and even boiling water. It may be cleaved, perhaps at different positions, either by acid treatment, as in present experiments, or by proteolytic enzymes, as is likely to occur in the proventricular tissue, giving origin to smaller active molecules.

Various active forms of the bombesin-like peptide were shown to occur in all the types of proventricular extracts examined.

The problem of whether forms of this peptide having a similar elution volume, found in different extracts, are identical or not must be left open. Similarly, the possibility must be considered that peptides found in acid extracts are, at least in part, artefacts arising from introconversion processes.

Also the bombesin-like peptide of the mammalian gut presents a clear-cut heterogeneity. The rat and guinea-pig stomach probably contains a probombesin giving origin, upon acid hydrolysis, to active forms. Moreover, it has been demonstrated in this laboratory that at least two biologically active forms occur in methanol and acid extracts of the human gastric mucosa and that three radioimmunoreactive forms may be detected in boiling water extracts of the same tissue.

\section{References}

Brown, M., Rivier, J., Kobayashi, R., and Vale, W. (1978). Neurotensin-like and bombesin-like peptides: CNS distribution and actions. In Gut Hormones, pp. 550-558. Edited by S. R. Bloom. Churchill Livingstone: Edinburgh and London.

Erspamer, V., Falconieri Erspamer, G., Inselvini, M., and Negri, L. (1972). Occurrence of bombesin and alytesin in extracts of the skin of three European discoglossid frogs and pharmacological actions of bombesin on extravascular smooth muscle. British Journal of Pharmacology, 45, 333-348.

Erspamer, V., and Melchiorri, P. (1975). Actions of bombesin on secretions and motility of the gastrointestinal tract. In Gastrointestinal Hormones, pp. 575589. Edited by J. C. Thompson. University of Texas Press: Austin. 
Erspamer, V., and Melchiorri, P. (1976). Amphibian skin peptides active on the gut. Journal of Endocrinology, 70, 12P-13P.

Erspamer, V., and Melchiorri, P. (1977). Polypeptides of the amphibian skin active on the gut and their mammalian analogues. International Symposium on Gastrointestinal Hormones and Pathology of the Digestive System. Rome, June 13-15. Abstracts, pp. 14-17.

Erspamer, V., Melchiorri, P., Falconieri Erspamer, G., and Negri, L. (1978). Polypeptides of the amphibian skin active on the gut and their mammalian counterparts. Advances in Experimental Medicine and Biology, 106, 51-64.

Greenwood, F. C., Hunter, W. M., and Glover, J. S. (1963). The preparation of ${ }^{131}$ I-labelled human growth hormone of high specific radioactivity. Biochemical Journal, 89, 114-123.

Lechago, J., Holmquist, A. L., and Walsh, J. H. (1978). Localisation . f a bombesin-like peptide in frog gastric mucosa by ir imunofluorescence and RIA. (Abstract) Gastroenterol.ngy, 74, 1054.

McDonald, T. J., Nilsson, G., Vagne, M., Bloom, S. R., Ghatei, M., und Mutt, V. (1978). Purification of a oorcine intestinal peptide with bombesin-like proper- ties. (Abstract) Scandinavian Journal of Gastroenterology, 13, suppl. 49, 119.

Polak, J. M., Bloom, S. R., Hobbs, S., Solcia, E., and Pearse, A. G. E. (1976). Distribution of a bombesinlike peptide in the gastrointestinal tract of man. Lancet, 1, 1109-1110.

Polak, J. M., Buchan, A. M. J., Czykowska, W., Solcia, E., Bloom, S. R., and Pearse, A. G. E. (1978a). Bombesin in the gut. In Gut Hormones, pp. 541-543. Edited by S. R. Bloom. Churchill Livingstone: Edinburgh and London.

Polak, J. M., Ghatei, M. A., Wharton, J., Bishop, A. E., Bloom, S. R., Solcia, E., Brown, M. R., and Pearse, A. G. E. (1978b). Bombesin-like immunoreactivity in the gastrointestinal tract, lung and central nervous system. (Abstract) Scandinavian Journal of Gastroenterology, 13, suppl. 49, 148.

Rehfeld, J. F. (1978). Multiple molecular forms of cholecystokinin. In Gut Hormones, pp. 213-218. Edited by S. R. Bloom. Churchill Livingstone: Edinburgh and London.

Walsh, J. H., and Dockray, G. J. (1978). Localisation of bombesin-like immunoreactivity (BLI) in gut and brain of rat. (Abstract) Gastroenterology, 74, 1108. 